\title{
FENOMENA BAHASA NAMA DALAM BUDAYA JAWA: KAJIAN ASPEK FILOSOFIS DAN FAKTA SOSIAL
}

\author{
Udjang Pr. M. Basir \\ Fakultas Bahasa dan Seni UNESA \\ Pos-el: udjangjw@yahoo.co.id
}

\begin{abstract}
Abstrak
Nama dalam budaya Jawa tidaklah sekedar identitas belaka. Di dalamnya terkandung berbagai makna terselubung yang terkait dengan hidup dan perikehidupan masyarakat secara tradisi dan filosofi. Tradisi budaya yang umumnya berkembang secara turun-temurun itu merupakan potret sosial nyata tentang pola pemikiran dan keyakinan yang ada dalam komunitas masyarakatnya. Fenomena tersebut masih berkembang hingga saat ini. Sebagian masih menjadi keyakinan ritualistik masyarakat Jawa secara masif, tetapi tidak sedikit yang menggunakannya sebagai identitas budaya semata. Lebih dari itu ada pula yang memanfaatkannya sebagai unsur pembeda (brand) untuk kepentingan promosi dan kompetisi bisnis di tengah era globalisasi. Dengan konsep sosiopragmatik (didaktik) dan pendekatan semioantropologi (filsafat), sajian data akan digali menggunakan metode deskriptif dengan teknik observasi, dokumentasi, dan wawancara terbatas terkait dengan aspek latar penamamaan, tujuan, sumber rujukan, pemahaman dan fakta sosial. Vokus bahasan akan dipusatkan pada aspek fenomena penggunaan bahasa nama dalam budaya Jawa yang terkait dengan nama anak (orang).
\end{abstract}

Kata kunci: fenomena, bahasa nama, budaya Jawa, filosofi, fakta sosial

\section{LANGUAGE PHENOMENA OF NAMES IN JAVANESE CULTURE: STUDY OF PHILOSOPHICAL ASPECT AND SOCIAL FACTS}

\begin{abstract}
The name in Javanese culture is not just merely an identity. It contains a variety of hidden meanings related to life, traditional and philosophical value of life. Cultural tradition that generally develops from generation to generation is a real social portrait of the patterns of thought and belief that exist in the society. The phenomena is still developing recently. Some of them still become ritualistic beliefs of mostly Javanese society, and many of them use it only as cultural identity. More than that there is also Javanese people use names as a differentiator for the benefit of promotion and business competition in the globalization era. With the concept of sociopragmatic and semioanthropological approach, the data presentation will be extracted by using the descriptive method with observation, documentation, and limited interviewing techniques related to aspect of naming backgrounds, objectives, referral sources, understanding and social facts. The focus of the discussion will be concerned on the phenomenon of the use of language of name in Javanese culture that is related to the name of the child.
\end{abstract}

Keywords: phenomena, language of name, Javanese culture, philosophy, social facts 


\section{PENDAHULUAN}

Nama dalam budaya Jawa, khususnya yang berkaitan dengan nama orang, bukan sekedar identitas diri, akan tetapi di dalamnya sarat dengan berbagai atribut simbolik dan nilai filosofi. Nilai filosofi yang ada berkaitan dengan pandangan hidup masyarakat dan harapan orang tua terhadap kehadiran anak. Anak bukan sekedar bentuk konsekuensi logis dari hasil hubungan "sebadan" antar kedua orang tuanya semata, tetapi di dalamnya terkandung makna sebagai pengikat tali perkawinan, penghibur, penyambung sejarah, pewaris ekonomi, dan kebanggaan keluarga. Karenanya, orang tua (ayah dan Ibu) akan membimbingnya ke arah kedewasaan yang maksimal, mulai dari masa kanak-kanak hingga dewasa. Mereka akan membimbing tentang pendidikan, budi pekerti, kepuasan emosional (kesenangan), pergaulan sosial, dan nilainilai kebudayaan Jawa yang umum, dan mendasar.

Tidak jarang keretakan rumah tangga diawali ketidakhadiran anak. Keharmonisan hubungan dan cinta kasih antar suami istri lambat laun akan luntur tanpa kehadiran anak sebagai buah hatinya. Anak menjadikan rumah tangga menjadi semarak, tumbuh motivasi kerja, dan semangat hidup semakin kuat. Motivasi tersebut tumbuh berkaitan dengan anak sebagai generasi penerus dan penyambung sejarah hidupnya yang akan memberikan jaminan kedamaian di masa tua. Hasil jerih payahnya (ekonomi) bernilai guna karena anak sebagai pewaris mendominasi seluruh hidup dan kehidupannya. Oleh karena itu wajarlah apabila seluruh waktu, pikiran, dan tenaga orang tua ditujukan untuk kebahagiaan anak, mulai dari penyediaan sandang, pangan, papan, pendidikan, dan sarana penunjang lainnya yang memungkinkan dapat mengantarkannya pada tataran kehidupan yang lebih dari padanya.
Anak sebagai generasi langsung, biasanya memiliki perangai dan karakter yang tidak jauh dari kedua orang tuanya. Hal itu disebabkan rentang waktu yang panjang dihabiskan anak di lingkungan keluarga bersama ayah dan ibunya. Untuk itu sebagai tanggung jawab moral, orang tua membekalinya dengan sejumlah norma sosial yang nantinya akan berguna sebagai bekal dalam pergaulan hidup bermasyarakat yang lebih luas bagi pendewasaan sang anak (Soedarsono. RM, Gatut Murniatmo. 1986). Dalam tradisi Jawa, bahkan luapan kegembiraan orang tua diungkapkan dalam berbagai bentuk. Selain berbagai hal di atas, kebanggaan dan harapan orang tua juga diperlihatkannya dalam pemberian inisial nama anak (bahasa nama). Pada umumnya bahasa nama dibuat sedemikian rupa, sehingga di dalamnya mewakili pikiran orang tua yang berupa harapan, cita-cita, kenangan, pesan, dan berbagai pencitraan lainnya (Koentjaraningrat, 1984).

Sehubungan dengan hal itu, dalam tulisan ini akan diulas secara garis besar bagaimana bahasa nama memiliki maknanya yang khusus sebagai ungkapan pikiran, perasaan, dan harapan orang tuanya. Lebih dari itu kajian akan diarahkan pada aspek-aspek yang berkaitan dengan nilai filosofis didaktis yang dapat mewarnai hidup dan kehidupan anak sebagai pembawa amanah dan harapan keluarganya. Fenomena lain kecenderungan penggunaan bahasa nama dikaitkan dengan brand tradisi Jawa juga terlihat pada nama tempat (desa/kota, bangunan, jalan, gunung, punden), senjata/ajian, makanan, lembaga, dan dunia bisnis.

\section{METODE}

Metode deskriptif digunakan dalam penelitian ini, dan teknik yang digunakan adalah observasi, dokumentasi, dan wawancara terbatas terkait dengan aspek latar penamamaan, tujuan, sumber rujukan, 
pemahaman dan fakta sosial. fokus bahasan akan dipusatkan pada aspek fenomena penggunaan bahasa nama dalam budaya Jawa yang terkait dengan nama anak (orang).

\section{HASIL DAN PEMBAHASAN}

Tulisan ini secara khusus akan membedah fenomena yang ada budaya Jawa terkait dengan identitas nama yang dikaitkan dengan nilai tradisi dan fakta sosial yang berkembang di lingkungan masyarakat modern. Sebagian ada yang konsisten menempatkan bahasa nama sebagai bagian dari ritual budaya yang diyakini memiliki dampak baik secara psikologis maupun arah takdir. Sekalipun demikian tidak jarang bahasa nama hanya sebagai identitas dan asesoris belaka tanpa terkait dengan pemahaman makna apalagi nilai filosofisnya. Karenanya kajian dalam tulisan ini diarahkan pada pembahasan bahasa nama anak (orang) dengan berbagai latar belakang dan fenomenanya (Ohoiwutun Paul, 1987).

Dalam tulisan ini bermaksud mengangkat sebagian dari hasil penelitian terbatas dalam rangka penyebarluasan informasi kepada komunitas masyarakat Jawa saat ini yang sudah mulai "pudar" penghargaannya terhadap budaya luhur bangsa sendiri. Sebagaimana judul tulisan ini, maka vokus bahasan akan diarahkan pada kajian bahasa nama dalam konteks nilai filosofis yang melatarbelakanginya dan fakta sosial yang berkembang di masyarakat saat ini.

Secara naluriah, pemakai bahasa berkomunikasi menggunakan bahasa yang hidup dan berkembang di masyarakatnya. Penggunaan bahasa itu terasa lebih mengakar, akrab, dan mewakili alam pikiran/perasaan secara total dan ekspresif. Dalam konteks yang lebih luas, penggunaan bahasa semacam itu dapat mengikat komunitas pemakainya menjadi satu masyarakat yang bersatu, kuat, dan maju.
Penggunaan bahasa Indonesia sebagai alat komunikasi antar etnik, yang kini penggunaannya semakin luas di kalangan masyarakat umum, tidaklah bebas dari pengaruh bahasa dan budaya daerah yang dimiliki dan dikuasai oleh para pemakainya, termasuk budaya Jawa. Aspek simbiosis semacam itu membuktikan bahwa budaya itu lentur, akomodatif, dan kontektual. Bahasa nama dalam budaya Jawa pembentukannya melibatkan aspek sosial dalam masyarakat terkait dengan konteks fungsi sosial tertentu (sosiopragmatik) dan pemaknaannya bersifat filosofis simbolis (semioantropologis). Untuk melihat keterkaitan antara bahasa dan masyarakat akan dibahas mengenai: (1) bahasa dan tingkat sosial, dan (2) bahasa nama: bentuk, model, dan makna.

\section{Bahasa dan Tingkat Sosial Masyarakat}

Secara budaya di masyarakat tradisional terdapat tingkatan sosial. Dalam kasus di masyarakat Jawa paling tidak dapat dilihat dari dua aspek: pertama, dari segi kebangsawanan, dan kedua, dari segi kedudukan sosial (pendidikan dan tingkat ekonomi). Dengan pendidikan lebih baik kemungkinan akan memperoleh taraf perekonomian lebih baik pula, sekalipun itu tidak mutlak.

Mengenai tingkat kebangsawanan ini, Kuntjaraningrat membagi masyarakat Jawa atas empat tingkat, yaitu: (1) wong cilik, (2) wong sudagar, (3) priyayi dan (4) ndara. Sedangkan Clifford Geertz (dalam Chaer, 1995) membagi masyarakat Jawa menjadi tiga tingkat, yaitu: (1) priyayi, (2) bukan priyayi tetapi berpendidikan dan bertempat tinggal di kota, (3) petani dan orang kota yang tidak berpendidikan. Dari kedua penggolongan itu, jelas adanya perbedaan tingkat dalam masyarakat tutur Bahasa Jawa. Dalam masyarakat kota yang heterogen dan multi etnis tingkat status sosial berdasarkan derajat kebangsawanan mungkin sudah tidak ada, sebagai gantinya 
ada lapis tingkatan dilihat dari status sosial ekonomi.

\section{Bahasa Nama: Bentuk, Model, dan Makna}

Secara umum nama merupakan suatu identitas atau disebut sebagai tanda pengenal. Tidak jarang seseorang memanggil nama dengan model panggilan. Untuk lebih jelasnya pada bagian ini akan dibabahas tentang: (1) nilai anak dalam masyarakat Jawa, (2) bentuk model, dan makna bahasa nama.

\section{Nilai Anak dalam Masyarakat Jawa}

Perkawinan adalah peristiwa alamiah yang bersifat universal dan berlaku bagi semua makhluk hidup. Artinya bahwa perkawinan ini merupakan kejadian alam yang berlaku bagi semua mahluk hidup di muka bumi ini, yang berlaku bagi binatang, tumbuhan, dan manusia. Bagi manusia, perkawinan merupakan peristiwa budaya yang sakral dan berbeda-beda bagi setiap masyarakat baik dalam hal persiapan, proses, ataupun pelaksanaannya. Hal itu dapat diamati dari berbagai prosedur yang unik dan beraneka ragam baik dalam hal persyaratan, rangkaian upacara, tradisi perkawinan, dan jenis prosesi adat dari awal, pelaksanaan, atau akhir dari upacara (Soedarsono, 1986).

Dalam kehidupan keluarga Jawa, baik di desa maupun di kota, mempunyai anak merupakan sesuatu yang didambakan. Ketidakhadiran anak dalam suatu keluarga akan menimbulkan suasana hampa, monoton, dan membosankan. Tidak jarang keretakan keluarga disebabkan tidak hadirnya anak. Sebaliknya, adanya anak akan memperkuat ikatan emosional suatu keluarga. Hadirnya anak menjadikan suasana hangat, semangat, dan menimbulkan rasa damai serta ketentraman keluarga (Kuntjaraningrat, 1984).

Pada kebanyakan orang Jawa, kehadiran anak menjadi pertimbangan utama dalam perkawinan. Bahkan tidak hanya itu saja, dalam masyarakat tradisional pementingan hadirnya anak laki-laki dipandang lebih utama daripada anak perempuan. Hal itu dapat difahami sebab anak laki-laki bagi kaum petani dipandang sebagai aset ekonomi yang dapat mendukung dan membantu orang tua bekerja di ladang atau di sawah. Demikian utamanya perihal jenis kelamin yang diinginkan keluarga, sehingga sering terjadi keadaan yang tragis, terutama dialami kaum perempuan. Mereka dimadu dan diceraikan karena tidak dapat memberikan keturunan anak laki-laki. Kehadiran anak dalam suatu keluarga selain dapat mencairkan kebekuan suasana keluarga, juga dapat memberikan keuntuingan emosional, ekonomi, maupun keuntungan sosial (Soedarsono, 1986).

Selanjutnya dikatakan bahwa keberadaan anak dapat berdampak 2 hal, yaitu bersifat positif (menguntungkan) dan negatif (tidak menguntungkan). Hal positif, memiliki anak menimbulkan perasaan puas karena adanya 3 keuntungan:

(1) Keuntungan emosional, yaitu berupa adanya rasa kebahagiaan, kecintaan, tidak kesepian, pertemuan, dan penerus keturunan.

(2) Keuntungan ekonomi, misalnya bantuan ekonomi rumah tangga, menjamin hari tua, dan membawa rejeki.

(3) Keuntungan sosial, yaitu berhasil membentuk watak dan kepribadian anak, pengakuan sosial, dan harga diri.

Namun demikian bagi keluarga, kehadiran anak juga dapat bernilai negatif. Hal itu dapat ditunjukkan dalam berbagai macam beban yang dirasakan atau harus dipikul orang tua. Beban karena hadirnya anak dalam suatu keluarga, yaitu:

(1) Beban perasaan, misalnya rasa takut kalau anak sakit, nakal, merusak barang-barang dan alat rumah tangga.

(2) Beban ekonomi, seperti pengeluaran biaya perawatan, pemeliharaan anak, pendidikan, kesehatan. 
(3) Beban ruang dan gerak, yaitu membatasi kegiatan dan kesempatan dalam bermacam-macam aktivitas sosial, ekonomi dan rekreasi.

(4) Beban fisik, terutama menambah pekerjaan.

(5) Beban kemasyarakatan, yaitu menambahnya jumlah penduduk.

Oleh karena itu, anak perlu dididik secara memadai, diberikan pendidikan agama yang cukup dan pencerahan moralitas yang sesuai dengan budayanya. Selain tanggung jawab tersebut, manusia (orang Jawa) sebagai makhluk yang beragama sering menitipkan dan menyelipkan harapan spiritual melalui pemberian identitas diri pada anak yang mengandung makna-makna tertentu, sesuai dengan harapan orang tua. Bahasa nama pada anak dirancang sedemikian rupa sehingga diharapkan memiliki tuah yang baik pada perkembangannya menuju manusia dewasa yang sesuai dengan harapan orang tua. Oleh karena itu pemberian nama pada anak dalam kehidupan masyarakat Jawa, secara tradisi menempati posisi yang penting. Hal itu terbukti dari adanya serangkaian prosesi tertentu untuk memberikan nama pada seorang anak. Dalam budaya Jawa pemberian nama diri seseorang (anak) merupakan matarantai yang tidak terpisahkan dari peristiwa sakral mulai perkawinan, kehamilan, kelahiran, dan pemberian nama.

C. Gertz (Kuntjaraningrat, 1984) mengatakan bahwa anak telah banyak mendapatkan perhatian orang tua jauh sebelum dilahirkan. Pada saat kehamilan 4 bulan, keluarga Jawa mengadakan upacara "kupatan" (ngupati), yang bertujuan untuk mengadakan upacara ucapan syukur kepada Tuhan YME karena doanya terkabul untuk mendapatkan calon anak yang diharapkannya. Pada saat kehamilan 7 bulan, bayi juga diselamati dengan upacara mitoni (7 bulan) atau yang umum dinamakan tingkeban. Upacara ini berbeda dengan upacara kupatan yang lebih mengarah pada upacara syukuran murni. Dalam upacara tingkeban ini lebih bermakna simbolik dalam rangka menyambut kelahiran bayi agar selamat (bayi dan ibunya) dan berjalan lancar. Sejumlah sesaji disiapkan, yaitu 7 buah nasi tumpeng dengan 7 jenis lauk-pauk, serta 7 jenis jenang jadah (nasi ketan) dengan warna yang berbeda-beda. Salah satu di antaranya, jenang procot yang bermakna cepat keluar. Demikian pula harinya tidak sembarangan tetapi dicarikan hari Setu Wage (Sabtu Wage). Baik jenang procot ataupun setu wage (metu age) mengandung makna simbolik atau harapan agar sang bayi cepat keluar saat dilahirkan.

Demikian menjelang kelahiran sang bayi (kehamilan 9 bulan) diadakan slametan lagi, yaitu slametan memuli saderek (selamatan menghormati saudara bayi). Upacara selamatan itu bertujuan untuk mendoakan saudara kembar bayi, yaitu kakang kawah (air ketuban) dan adi ari-ari (ari-ari) agar membantu mempermudah kelahiran bayi. Air ketuban (kakang kawah) dianggap saudara tua bayi karena keluar lebih dahulu untuk memberikan kemudahan jalan sang bayi. Sedangkan ari-ari (adi ari-ari) dianggap saudara muda sebab keluar belakangan setelah bayi dilahirkan. Keduanya dalam keyakinan adat Jawa dianggap memiliki roh (hidup) yang kelak akan selalu melindungi bayi. Setelah sampai saatnya kelahiran bayi (9 bulan 10 hari) maka pertolongan dukun bayi, bidan, atau dokter dilakukan. Pada kondisi saat ini sudah banyak yang menggunakan jasa dokter di puskesmas-puskesmas atau di rumah sakit. Setelah kelahiran bayi sampailah saatnya pada upacara pemberian nama yang tidak kalah pentingnya.

Dalam adat budaya Jawa upacara pemberian nama biasanya diadakan pada hari kelima (sepasar). Upacara selamatan itu biasa disebut slametan brokohan. Kata brokohan itu sendiri berasal dari kata 
bahasa Arab, yaitu barokahan yang berarti upacara untuk mendapatkan berkah dari Tuhan (Allah) yang dapat mendatangkan kebaikan bagi keluarga dan bayinya. Keluarga Jawa santri biasanya melaksanakan upacara pemberian nama pada hari sepasar dengan upacara korban atau kekah. Kekahan sendiri dilakukan dengan memotong hewan korban (umumnya kambing) untuk dibagikan kepada tetangga dan fakir miskin (Kuntjaraningrat, 1984:104). Namun dalam keyakinan lain, kekah dilakukan untuk selamatan hari ke 1000 (nyewu) orang yang telah meninggal (Poerwadarminta, 1939:195).

\section{Bentuk, Model, dan Makna Bahasa Nama}

Dalam keyakinan tradisi Jawa, nama bukanlah sekedar identitas diri. Berbicara tentang nama (baca: bahasa nama) yang umum dikenal di berbagai lingkungan masyarakat (tradisional), biasanya terkait dengan aspek filosofi komunitas masyarakatnya (Koentjaraningrat, 1984; Ciptoprawiro, 1986; Haryanto S., 1992).

Dalam komunitas Jawa, nama diri selain memiliki maknanya yang khas, juga bentuknya satu sama lain tidak sama. Demikian halnya dalam masalah panggilan (cara menyapa) juga terdapat variasinya sendiri. Hal itu cukup menarik untuk dikaji, sebab selain mengindikasikan satu karakter budaya yang khas, juga memiliki nilai filosofi yang berkaitan dengan hakekat hidup dan perikehidupan orang Jawa. Selain itu kajian ini akan melibatkan disiplin ilmu sosial, budaya, dan bahasa (linguistik). Dengan kondisi yang demikian, yaitu tentang "aspek bahasa nama" dalam budaya Jawa yang akan ditelusuri secara konteks bentuk (bahasa) dan latar belakang yang menyertai munculnya sebuah nama diri relatif lebih berperspektif sebagai kajian bahasa dalam tataran sosiopragmatik. Sosiopragmatik sendiri merupakan kajian fakta bahasa yang dikaitkan dengan dimensi-dimensi konteks yang sifatnya situasional dan sosiokultural. Konsep itu merupakan reaksi pada faham strukturalis yang kaku dan tektual dalam memahami bahasa.

Terkait dengan bahasa nama pada anak dalam budaya Jawa, sarat akan berbagai dimensi sosiokultural, budaya, dan nilai filsafat tertentu. Karenanya bahasa nama dapat berimplikatur doa, keyakinan, cita-cita, peringatan, atau kenangan. Oleh karena itu dalam pemberian nama pada anaknya, orang tua selalu mengkaitkannya dengan ritual-ritual tertentu, seperti minta petunjuk pada orang tua (sesepuh), kyai atau dukun. Selain itu juga dengan disertai dengan doa dan selamatan (kenduri) yang disaksikan para tetangga dan sanak famili.

Dalam budaya Jawa memberikan nama pada anak dengan serangkaian ritual dan menyematkan sejumlah makna tertentu (doa, kenangan, harapan, peringatan) yang tidak jarang disertai perhitungan dan ramalan masa depan tentang nasib anak. Nama yang melekat pada diri anak Jawa merupakan bentuk komunikasi magis (doa atau harapan) kepada tuhan dan masyarakat sekitar. Umumnya memberikan nama pada anak melalui perhitungan tradisi, dengan minta petunjuk sesepuh dan ritual keagamaan agar terkabul harapannya. Deretan nama berikut memiliki maknannya yang khas filosofis, misanya Budi Santoso (orang yang tabah/kokoh pendirian), Kuntjaraningrat (orang terkenal di dunia), Priya Jatmika (laki-laki yang tampan), Slamet (selamat), Tupon (anak yang lahir hari Saptu, pasaran Pon), Sri Rahayuningsih (wanita cantik yang selalu dilindungi Tuhan), Febri Wasono Aji (anak bungsu hebat yang lahir bulan Februari), dll.

Nama seseorang ada yang panjang ada pula yang pendek. Nama yang panjang ada yang terdiri dari dua, tiga, empat kata bahkan lebih. Misalnya: Agung Pambudi (pekerja keras), Resdianto Permata Raharjo 
(pria hebat dan beruntung), Joko Satriyo Agung (pria pemberani dan berwibawa), dll. Dalam pergaulan sehari-hari saat bercakap-cakap, bertegur sapa, dan memanggil tentunya tidaklah seluruh bagian nama itu disebutnya. Penyebutan nama itu bisa salah satu bagian nama, singkatan, atau nama tambahan. Bentuk komunikasi yang demikian ini dinamakan paraban (panggilan/sapaan). Menyapa seseorang ada yang menggunakan cara menyebut salah satu bagian nama keseluruhan. Nama Agung Pambudi ada yang dipanggil Agung (Nak Agung, Mas Agung, Pak Agung); ada pula yang kadangkala dipanggil Budi (Nak Budi, Mas Budi, Pak Budi). Demikian pula dengan nama-nama lainnya, pemanggilan itu biasanya berdasarkan perjanjian atau kebiasaan. Namun dalam konteks bertegur sapa dan dalam kondisi khusus, misalnya di jalanan, saat berpacaran, dll. panggilan nama itu biasanya penyebutannya tidak utuh, misalnya Gung (Agung), Pras (Prasetyo), Mas (Emas), Dik (Adik), Jeng (Adi Ajeng), dan lain sebagainya.

Masih ada lagi salah satu bentuk panggilan akrab berkonotasi kurang baik, tapi terdapat dalam masyarakat. Istilah yang digunakan biasanya terkait dengan sifat yang melekat dan tampilan fisik. Misalnya, panggilan Wuk atau Bawuk (anak wanita, kelamin wanita), Le_atau Thole (anak laki-laki, kelamin lelaki). Ada juga panggilan Peng atau Gepeng (karena kepalanya benjol, peang), Ndul atau Gundhul (karena botak), Dheklong (kakinya cacat sebelah), Wor atau Klowor (mulutnya lebar), Dor atau Bedor (matanya besar), Bemo (panggilan Mandra, karena mulutnya monyong), Jitheng atau Jlitheng (karena kulitnya hitam), dan lain sebagainya.

Pembahasan mengenai aspek kata dan identitas nama di atas tentu bukan sekedar menyangkut aspek linguistik belaka, namun yang lebih penting menyangkut perannya dalam konteks sosial. Demikian pula penyebutan nama dan panggilan terhadap seseorang, dalam konteks budaya tertentu (Jawa, misalnya), di dalamnya juga bermakna sebagai doa, cita-cita, harapan, atau kenangan tertentu (sedih, gembira) dari kedua orang tuanya di masa lalu. Fenomena yang demikian menjadi bagian dari model pembahasaan faham idealis seperti ilmu filsafat (filsuf), dan sekaligus merupakan bagian peristiwa sosial budaya masyarakat (sosiologi) yang secara maknawi dapat ditelusuri melalui konstelasi bahasa dan konteks sosial (sosiolinguistik) dan implikatur makna yang tertsirat (sosiopragmatik) sebagai produk refleksi sosiobudaya pada masyarakatnya. Eksistensi bahasa nama, khususnya dalam budaya Jawa, umumnya masih dipandang sebagai sesuatu yang bernilai magis (bertuah). Artinya, melalui nama yang diberikan kepada seseorang (anak) akan memiliki pengaruh dan daya sugesti terhadap nasib masa depannya. Oleh karena itu sangat wajar apabila memberikan nama (anak) dalam tradisi Jawa melalui serangkaian ritual tertentu yang tatacaranya dilakukan berdasarkan aturan adat atau kepercayaan yang bersumber dari seorang dukun, kyai, tokoh masyarakat, sesepuh (kakek-nenek, orang yang dituakan, dll.). Ritual yang umum dilakukan sebagian masyarakat Jawa, terutama masyarakat tradisionalnya, biasanya diperoleh dari berbagai cara, misalnya: (1) bertanya pada kyai, dukun, orang pintar, paranormal, dll; (2) puasa, solat tahajud; (3) mimpi atau bisikan gaib; (4) perhitungan berdasarkan primbon; (5) hari lahir, pasaran, jam kelahiran, bulan, dan (6) peristiwa-peristiwa tertentu yang dipandang sangat berkesan. Secara umum, prosesi menentukan dan memilih bahasa nama untuk anak di lingkungan masyarakat Jawa seperti tergambar pada diagram di bawah ini. 


\section{PROSESI LAHIRNYA BAHASA NAMA DALAM BUDAYA JAWA}

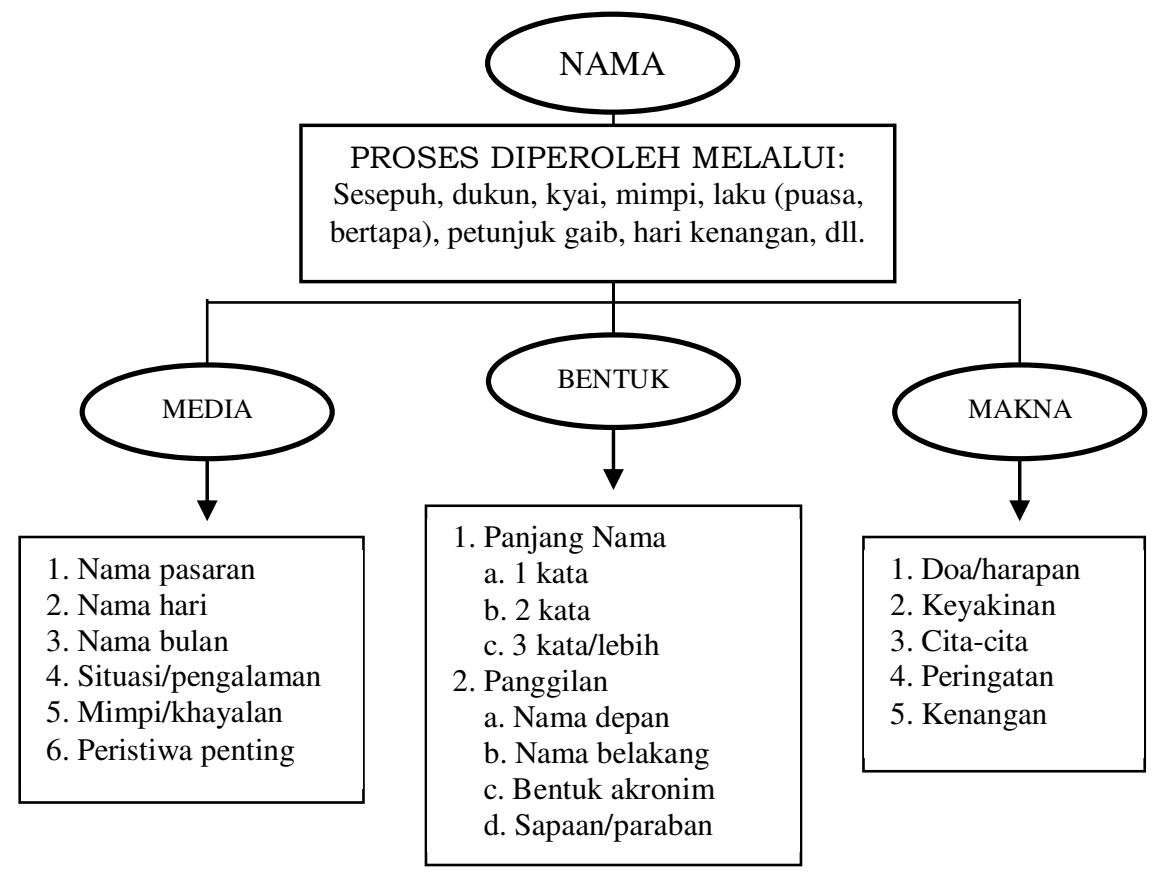

\section{Aspek Nilai Bahasa Nama dalam Tradisi Jawa}

Sebagaimana diulas pada bagian pengantar dan dasar pemikiran, bahwa nama yang diberikan orang tua dalam budaya Jawa umumnya bukan sekedar bermakna identitas diri. Secara tradisi yang relatif masih berlaku, bahwa pemerolehan bahasa nama untuk seseorang (anak) bukanlah asal jadi, tetapi melalui proses ritual yang bernilai magis. Bahkan jauh sebelum kelahiran anak, proses yang bernilai religius itu itu sudah dimulai, seperti yang kita kenal dengan istilah ngupati (selamatan kehamilan 4 bulan), mitoni atau tingkeban (selamatan kehamilan 7 bulan). Setelah kelahiran anak, persiapan pemberian nama anak dilakukan dengan berbagai perhitungan baik menyangkut hari, pasaran, jam, peristiwa alam, kenangan, cita-cita, dan lain sebagainya. Realisasinya menghasilkan ungkapan bahasa nama yang tidak saja sebagai identitas pribadi (panggilan), tetapi di dalamnya lebih bernilai filosofis (semioanropologis) dan didaktik (sosiopragmatis).
Dalam tradisi Jawa yang masih memegang teguh adat budaya, khususnya di pedesaan, permberian nama pada anak disertai prosesi ritual adat tertentu. Selain diawali sewaktu anak masih dalam kandungan, dengan acara selamatan ngupati dan tingkeban, maka setelah kelahiran juga disertai upacara selamatan pemberian nama. Pemberian nama dilakukan pada saat anak berumur sepasar (lima hari), setelah sebelumnya dilakukan ritual muyenan atau jagong bayen setiap malam. Dalam acara itu mengundang segenap warga tetangga dan tokoh adat, dilakukan puji-pujian dengan menggunakan medium tembang (biasanya tembang macapat) dan kidungan (tembang gedhe dan tengahan) yang isinya mendoakan sang bayi agar diberikan umur panjang, tuntunan ke jalan kebaikan, soleh, dan kelak dapat berbakti pada kedua orang tuanya.

Setelah hari kelima, dengan meminta pertimbangan sesepuh (ketua adat, nenek dan kakek, serta orang yang dituakan lainnya), maka berembug (diskusi) untuk memberikan nama pada sang bayi dengan 
mempertimbangkan hari kelahiran, neton, pasaran, bulan, peristiwa alam, kenangan, bahkan harapan dan cita-cita orang tua sering disertakannya. Hal itu nampak pada deretan nama-nama anak Jawa, seperti: Paing, Wage, Legi (pasaran), Tupon (hari dan pasaran), parjono (bulan Sapar), Yulianto (bulan Juli), Suprihatin (peristiwa menyedihkan: kematian, banjir, hidup sengsara), Eko Budiono (anak pertama), Dwi Apriliani (anak kedua lahir bulan April), Tri Budi Astuti (anak ketiga), Catur Pambudi (anak keempat), Sigit Cahyono (anak yang tampan dan menerangi), Kuntjaraningrat (termashur), dll.

\section{Nilai Filosofis}

Selain kecenderungan yang melatarbelakangi pemberian nama anak di atas, secara adat dan budaya Jawa, kehadiran anak bagi orang tua mengandung nilai-nilai filsapat yang sangat dalam. Paling tidak terdapat 7 aspek falsapah yang menyertai harapan lahirnya seorang anak bagi orang tuanya, yaitu: (1) anak sebagai titipan Tuhan, (2) anak sebagai penyambung sejarah, (3) anak sebagai pembawa rejeki, (4) anak sebagai buah cinta kasih, (5) anak sebagai pengikat cinta, (6) anak sebagai penghibur hati, dan (7) anak sebagai aset hari tua.

\section{Anak adalah Titipan Tuhan}

Masyarakat Jawa tergolong masyarakat yang agamis dan religius. Mereka meyakini, bahwa dalam kehidupan manusia di dunia ini ada yang mengaturnya, yaitu Tuhan (Hyang Maha Agung). Berkaitan dengan itu tumbuh keyakinan bahwa jodho, rejeki, lan pati iku ana astane Hyang Widi (jodoh, rizki, dan umur manusia berada di tangan Tuhan). Hal itu merupakan semboyan yang menjadikan orang Jawa hidup dengan penuh sabar, semangat, dan optimis. Hal jodoh, memunculkan ungkapan: wong urip $i k u$ jejodhoan (hidup itu berpasangpasangan), durung jodhone (belum berjodoh). Hal rizki memunculkan ungkapan: Gusti iku adil (Tuhan itu maha adil), urip iki nyakra manggilingan (hidup ini seperti roda, terkadang berada di atas 'kaya' terkadang juga ada di bawah 'miskin'). Hal hidup (pati) memunculkan ungkapan: wong urip iku bebasane mung mampir ngombe (hidup ini singkat, banyaklah berbuat baik untuk bekal mati), pati urip ana astane Gusti (hidup mati seseorang ada di tangan Tuhan), dan lain sebagainya.

Demikian pula diyakini bahwa anak itu titipan Tuhan. Oleh karena itu harus dirawat dengan baik agar tuhan memberikan berkat dalam kehidupan rumah tangga. Orang yang menyia-nyiakan anak akan mendapatkan murka tuhan dan akan dijauhkan dari kemurahan rizki dan kedamaian hidup. Untuk itu menjadi tanggung jawab orang tua untuk merawat, menyayangi, membimbing ke jalan kebaikan, mendidik dan menyekolahkan, menanamkan keyakinan agama, dll. Hal itu dimaksudkan agar kelak anak tumbuh menjadi pribadi yang soleh dan berbakti kepada orang tua. Sebaliknya, jika orang tua mengabaikan anak sebagai titipan Tuhan, maka ia akan berdosa dan di masyarakat akan menjadi bahan celaan orang.

\section{Anak adalah Penyambung Sejarah}

Memiliki anak bagi keluarga Jawa, selain bagian dari tujuan perkawinan, juga memiliki kebanggaan tersendiri. Bagi seorang suami, dirasakan telah menunaikan tugasnya sebagai lelaki (nganaki 'memberi anak'), sebaliknya bagi seorang istri, dengan punya anak dirinya berhasil membuktikan sebagai wanita sejati (memberikan keturunan). Keluarga yang tidak memiliki keturunan, sering mendapatkan predikat tidak mengenakkan, yaitu lanang wandu (banci), dan wong gabug (wanita tak berbenih). Dan keadaan semacam ini sering memicu keretakan dalam rumah tangga dan bahkan tidak 
jarang menjadi alasan perpisahan (perceraian).

Menyadari umur manusia yang terbatas dan kematian yang pasti datang, maka kehadiran anak dimaknai sebagai penyambung sejarah. Orang tua akan termotivasi untuk bekerja, mencari nafkah seharian karena terdapat anak yang menunggu dan menjadi tanggung jawabnya. Selain itu semua materi, kekayaan, dan harta benda sebagai hasil kerja kerasnya tidak akan sia-sia karena ada anak yang akan mewarisi dan meneruskannya. Lebih dari itu nama seseorang akan dikenang oleh keluarga dan masyarakat karena ada anak-anaknya berhasil meneruskan jejak dan cita-citanya di masa datang. Apalagi jika berhasil mengantarkan anak keturunannya ke jenjang kehidupan yang lebih baik (sukses dan berpangkat), maka orang tua akan terangkat nama dan derajatnya sebagai orang tua yang berhasil. Konteks tersebut memunculkan ungkapan budaya yang sarat dengan nilai filosofis metaforistis: anak bisa ngangkat drajating wong tuwa, mikul dhuwur-mendhem jero (anak yang berhasil mengharumkan nama baik orang tua). Keberhasilan orang tua dalam mengantarkan kesuksesan anak, melahirkan ungkapan padhang dalane jembar kubure (mereka akan mati dengan tenang dan akan masuk sorga).

\section{Anak adalah Pembawa Rejeki}

Keyakinan ini terungkap dari pepatah yang berbunyi: akeh anak, akeh rejekine (banyak anak banyak rejeki); anak iku nggawa rejekine dhewe-dhewe (setiap anak akan membawa rezki yang berbeda-beda). Sekalipun ungkapan itu secara konteks tepat untuk jaman dulu, di mana setiap anak merupakan potensi sebagai tenaga kerja yang dapat membantu orang tua di sawah dan di ladang, tentu untuk masa kini (modern) tidak selaras benar. Bagi keluarga miskin bahkan kehadiran anak menjadi beban, sebab segala kebutuhan hidup mahal dan biaya pendidikan yang tidak murah.

Hal yang masih dapat ditarik benang merah dari ungkapan tersebut dalam konteks masa kini yaitu bahwa kehadiran anak menjadi pendorong motivasi kerja. Dengan dorongan motivasi kerja yang tinggi karena merasa ada anak yang menjadi tanggung jawabnya, maka penghargaan (bertambahnya penghasilan, kenaikan gaji dan pangkat) yang diraih dapat dipandang sebagai peran anak sebagai pendorong semangat kerja dan berdampak meningkatkan rizki orang tua.

\section{Anak adalah Buah Cinta Kasih}

Tidak dipungkiri bahwa perkawinan adalah sesuatu yang indah dan menggembirakan. Dua insan berbeda jenis kelamin saling dipertemukan dengan bekal cinta kasih. Keduanya saling memberi dan menerima untuk membangun keluarga yang diidamkan. Dari buah cinta kasih suami istri lahirlah anak-anak yang didambakan. Maka kelahiran dan kehadiran anak akan menambah semarak keluarga dan lekatnya jalinan cinta kasih suami istri.

Keluarga tanpa anak, bagai sayur tanpa garam. Cinta kasih umumnya dipengaruhi aspek fisikel (cantik dan tampan) karena usia muda. Maka seiring dengan umur yang semakin bertambah (tua), keindahan fisik semakin memudar, dan cinta kasih dapat luntur. Namun dengan hadirnya anak, maka kadar cinta kasih dapat ditransformasikan pada anak yang menjanjikan masa tua lebih terjamin (terjaga). Infestasi kasih sayang dan pendidikan pada anak diharapkan ada balas budi yang sepadan (baik) berupa perhatian dan kasih sayang terhadap orang tuanya di saat akhir hidupnya.

\section{Anak adalah Pengikat Tali Cinta,}

Dalam tradisi Jawa, kehadiran anak dalam suatu perkawinan masih menjadi persyaratan mengikat yang tidak tertulis. 
Selain berfungsi sebagai penyambung sejarah, pembawa rejeki, dan buah cinta kasih, anak juga berfungsi sebagai pengikat tali cinta kasih keutuhan keluarga (suami mistri).

Keluarga akan terasa sepi tanpa kehadiran anak. Maka berbagai usaha dilakukan keluarga, jika dalam rentang 3 sampai 5 tahun perkawinan belum menghasilkan anak. Istri sangat gelisah dan merasa terancam, karena akan diposisikan sebagai istri mandul (gabug) dan kemungkinan suami akan berpaling (menyeleweng) menjadi lebih besar. Akibatnya banyak istri yang karena tidak mempunyai anak menanggung nasib menyedihkan, harus dimadu atau diceraikan suami. Sebaliknya istri yang dapat mempersembahkan anak, akan semakin disayang mertua dan suami, sekalipun hal itu bersifat relatif juga.

\section{Anak adalah Penghibur Hati}

Berbicara tentang anak, konotasi yang timbul adalah sifat lucu, menarik, dan menggemaskan. Apalagi pada saat masa balita, kemenarikan sosok anak adalah pada fisik yang lincah, suara (bicara) yang lucu, tertawa dan tangisan yang membuat senang serta gelisah orang tua, dan lain sebagainya.

Ayah dan ibu bekerja seharian demi mencukupi kebutuhan dan kesenangan anak yang dicintainya. Rasa penat di badan, capek bekerja seharian akan terasa ringan bahkan hilang jika telah bertemu anak di rumah yang sehat dan menyenangkan. Bersama anak, ayah dan ibu akan merasa terhibur hatinya karena hidup terasa berguna dan bermakna

\section{Anak adalah Aset Hari Tua.}

Sangat disadari bahwa kekuatan fisik manusia sangatlah terbatas. Masa muda adalah masa produktif dan masa kerja. Masa itu merupakan era keemasan untuk perjuangan hidup dalam rangka menyiapkan hari tua. Oleh karena itu wajar jika masa itu diawali persiapan panjang dan matang melalui pendidikan untuk merebut kesempatan kerja yang lebih sesuai dan hasilnya memuaskan. Hal itu selain untuk mempersiapkan hidup berumah tangga, juga mempersiapkan masa depan anak-anaknya agar hidup lebih baik (sejahtera) dari dirinya.

Penyiapan kesejahteraan anak, diawali dari perhatian dan pemberian kasih sayang serta pendidikan yang cukup. Selain itu juga pengenalan aspek budaya dan keagamaan sebagai pelengkap agar anak memiliki karakter dan budi pekerti yang baik, soleh, berbakti pada orang tua, bermanfaat bagi orang lain (masyarakat), dan dapat hidup sejahtera. Keberhasilan hidup anak yang disertai budi pekerti yang baik akan menjamin masa depan orang tua lebih tenang hidupnya. Pendek kata hanya anak yang berhasil hidupnya dan berhati mulia yang akan dapat dijadikan pelindung keluarga (orang tua) di masa tuanya. Bahkan anak yang berbudi (soleh), akan menjadi pembuka pintu maaf Sang Khalik (Allah) dengan doa-doanya saat orang tua telah meninggal, selain amal jariah, dan manfaat ilmu yang diwariskan.

\section{Aspek Didaktis}

Aspek didaktis yang berkaitan dengan bahasa nama (nama diri) hanya akan didapat pada anak/orang yang mengerti benar akan makna nama dirinya. Nama diri (bahasa nama) jika itu dimengerti oleh yang menyandangnya, tentu akan merasa mendapatkan amanah (doa) dari orang tuanya. Dari kesadaran itu akan tumbuh pengertian dan rasa tanggung jawab moral serta berdosa jika dirinya berperilaku yang bersebrangan dengan makna nama (bahasa nama) yang dititipkan secara simbolistis pada dirinya.

Jika kesadaran adanya keterikan emosional dan tanggung jawab untuk mengoperasionalkan pesan bahasa nama dalam kenyataan, maka selain aspek budaya Jawa dapat dipertahankan, nilai- 
nilai didaktik (pendidikan) dalam rangkaian pesan yang tertuang dalam bahasa nama pada seseorang, secara budaya akan semakin berwibawa. Sebaliknya jika seseorang kurang mengerti akan makna nama diri dan mengingkarinya dalam tindakan nyata, maka selain cercaan masyarakat yang akan diperoleh, juga utamanya mengesankan sebagai sosok orang bodoh dan tak berbudaya. Nama diri (bahasa nama) yang bernilai didaktis, paling tidak terdapat 4 kategori, sebagai berikut:

\section{Makna Cita-Cita}

Tidak jarang orang tua yang gagal mencapai harapannya (sekolah, pekerjaan, dll) lalu berharap obsesinya dapat diwujudkan anaknya. Oleh karena itu nama sang anak dibuat sedemikian rupa sehingga menggambarkan satu harapan yang selama ini dicita-citakan orang tuanya. Lain dari pada itu pemberian nama pada sang anak juga kadangkala merupakan refleksi dari apa yang menjadi harapan orang tua kepada sang anak agar hidup bahagia kelak di kemudian hari. Sejumlah contoh berikut sebagai ilustrasinya:

(1) Koentjaraningrat

(2) Hamengku Buwono

(3) Mangku Bumi

(4) Dorojatun Kuncoroyekti

Keempat contoh data di atas adalah nama-nama yang sudah sangat popular di kalangan masyarakat Jawa. Data (1) Koentjaraningrat adalah seorang guru besar antropologi budaya Universitas Indonesia yang sangat kesohor. Dari aspek nama sesuai dengan cita-cita orang tuanya, anaknya terkenal di dunia akademik sebagai guru besar (Kuncara = terkenal, ningrat $=$ dunia). Data $(2)$ adalah nama raja dari Yogyakarta (Sri Sultan Hamengkubuwono) yang memiliki kekuasaan luas baik pada rakyat ataupun wilayahnya. Dari aspek semantiknya bermakna menguasai dunia (Hamengku = menguasai, Buwono = dunia). Data (3) adalah nama Mangkubumi yang bermakna mengusai wilayah $($ Mangku $=$ menguasai, Bumi = tanah, wilayah). Dan data (4) yaitu Darajatun Kuncarayekti (anak lelaki yang termashur), beliau adalah menteri perekonomian kabinet Presiden Megawati. Contoh lain tergambar pada beberapa nama sebagai berikut.

(5) Agus Subekti (anak pria yang berbakti)

(6) Agung Pranoto (laki-laki yang dapat memimpin)

(7) Rini Sulistyowati (anak perempuan yang cantik lahir batinnya)

(8) Endang Setyowati (anak perempuan yang penuh kesetiaan)

(9) Joko Tetuka (anak laki-laki yang jujur dan pemberani)

\section{Makna Doa dan Harapan}

Perasaan kasih sayang orang tua pada anaknya sebagai bagian dari tanggung jawab keluarga tidak sekedar dalam bentuk pemenuhan kebutuhan biologis (sandang pangan), tetapi juga dalam bentuk doa-doa yang setiap saat diungkapkan sesaat setelah melakukan kegiatan ibadah (solat, berdoa, dll). Selain itu doa orang tua yang berupa harapan-harapan terbaik bagi anaknya juga dituangkan dalam bentuk bahasa nama yang diberikan kepada anak-anaknya. Dengan doa dan harapan yang dititipkan melalui bahasa nama pada anaknya diharapkan setiap panggilan (memanggil) sekaligus bermakna doa orang tua. Sejumlah data berikut kiranya dapat memberikan ilustrasi tentang makna tersebut.

(10) Slamet Setyawan

(11) Dwi Astutik

(12) Ika Kurniawati

(13) Dyah Retno Dewi

(14) Sri Sulistyowati

(15) Siti Fitriyah

(16) Budi Jatmiko

Ketujuh data di atas jika dianalisis secara makna budaya akan memberikan pemahaman makna doa dan harapan. 
Sekalipun masing-masing nama memiliki nuansa maknanya sendiri, tetapi semuanya bermuara pada tujuan dan harapan yang baik bagi orang tua dan anaknya. Data (10) dan (11) pada hakekatnya memiliki makna yang tidak jauh berbeda, yaitu nama yang bermakna doa keselamatan dari orang tua. Bedanya Slamet Setyawan (anak lelaki yang diharapkan selamat hidupnya) untuk nama laki-laki, dan Dwi Astutik (anak kedua yang diharapkan selalu selamat dan berhasil hidupnya) untuk nama perempuan. Data (12) Ika Kurniawati bermakna anak pertama perempuan yang diharapkan hidupnya dapat karunia Tuhan (barokah). Data (13) Dyah Retno Dewi dan (14) Sri Sulistyowati berarti anak perempuan yang diharapkan cantik seperti bidadari. Data (15) Siti Fitriyah berarti anak perempuan yang diharapkan berhati suci dan jujur. Data (16) Budi Jatmiko memiliki makna anak laki-laki yang diharapkan memiliki hati yang lemah lembut.

\section{Makna Peringatan}

Kondisi keluarga tidak selamanya mengalami kehidupan yang menyenangkan. Kadangkala secara ekonomis mengalami pasang surut yang mempengaruhi kondisi kehidupan rumah tangga suatu keluarga. Pada saat roda ekonomi keluarga mengalami kejayaan, maka tidak jarang keadaan itu juga tercermin pada identitas nama anaknya yang lahir pada saat itu. Demikian pula jika kondisi keluarga memprihatinkan tidak jarang keadaan itu tercermin pada nama yang diberikan pada anak yang lahir pada saat keadaan buruk tersebut. Namun tidak sedikit bahwa hari, pasaran, dan bulan kelahiran juga dijadikan bahan "peringatan" bagi orang tua untuk memudahkan mengingat-ingat kelahiran sang buah hati. Contoh berikut dapat menjelaskannya:

(17) Suprihatin

(18) Ribut Waluyo

(19) Joko Subeno
(20) Yuli Sumantri

(21) Poniah

(22) Ngadinah

Data (17), (18), dan (19) pada hakekatnya merujuk pada situasi yang kurang lebih sama, yaitu perihal ketidaknyamanan kehidupan orang tua. Suprihatin (17) anak perempuan yang lahirnya saat orang tuanya dalam keadaan hidup sengsara. Ribut Waluyo (18) anak laki-laki yang lahirnya membuat suasana kacau, sedih (Ribut) karena lahir "sungsang" sehingga ibunya meninggal dan bayi itu hampir tidak tertolong, tetapi dengan kuasa Tuhan bayi itu selamat (waluyo). Joko Subeno (19) anak laki-laki yang lahir saat terjadi banjir (Beno). Yuli Sumantri (20) anak perempuan yang lahir bulan Juli dan anak dari bapak Sumantri. Poniah (21) anak perempuan yang lahir pada hari pasaran Pon. Sedangkan Ngadinah (22) berarti anak perempuan yang lahir pada hari Minggu (Ngaad).

\section{Makna Agamis dan Kepercayaan}

Seiring dengan kemajuan jaman, orang Jawa pun beradaptasi dengan perubahan ilmu pengetahuan dan teknologi. Perubahan tersebut bukan sekedar menyangkut perilaku dan gaya hidup saja, tetapi juga merasuk pada sendisendi budaya yang telah secara turuntemurun dianut oleh masyarakat Jawa. Imbas pemahaman agama merasuk pada perilaku budaya, perilaku berbahasa, dan bahkan masuk dalam pemberian identitas nama pada generasi mudanya. Perilaku budaya yang semula menjunjung tinggi peninggalan leluhur (tradisi), seperti cara berpakaian, sikap pada perilaku pada yang lebih tua, dsb. lambat laun semakin bergeser ke arah pembaharuan yang bersifat pragmatis. Demikian juga dengan bahasa Jawa terasa semakin berkembang ke arah yang semakin jauh dari norma standar budaya yang dianjurkan. 
Berkaitan dengan bahasa nama, pengaruh keyakinan agama dan ilmu pengetahuan semakin mewarnai "penamaan" anak-anak Jawa. Mereka yang beragama Islam, maka nuansa ke-Islaman nampak pada nama keluarga baru. Demikian pula meraka yang berkeyakinan agama Kristen, Katolik, Hidu, dll. memiliki pengaruhnya sendiri terhadap lahirnya bahasa nama yang diberikan pada anak keturunan Jawa modern ini. Gambaran tersebut tampak pada sejumlah contoh data nama berikut ini.

(23) Mohammad Sudiro

(24) Nurul Qomariyah

(25) Maria Sulistyaningsih

(26) Andreas Catur Wibowo

(27) Natalia Gita Wijaya

(28) Indra Krisnayana

(29) Dewi Proborini

Ketujuh data nama di atas lebih bernuansakan cita rasa keyakinan agama, baik Islam, Kristen, ataupun Kejawen (Hindu). Data pertama dan kedua adalah nama diri yang dipengaruhi keyakinan agama Islam. Mohamad Sudiro (23) nama Islam yang bermakna anak laki-laki baik yang diharapkan memiliki watak seperti nabi Muhammad. Nurul Qomariah (24) anak perempuan yang cantik indah seperti rembulan. Sedangkan data (25), (26), dan (27) erat kaitannya dengan nama yang bernafaskan keyakinan agama Kristen atau Katolik. Maria Sulistyaningsih (25) berarti anak cantik putra Bunda Maria. Andreas catur Wibowo (26) artinya anak laki-laki keempat yang diharapkan memiliki sifat keberanian seperti tokoh dalam Alkitab. Dan Natalia Gita Wijaya (27) bermakna anak perempuan lembut dan sukses yang lahir bulan Desember (natal). Sedangkan data dua terakhir lebih menggambarkan keyakinan Kejawen (Jawa-Hindu), yaitu Indra Krisnayana (28) bermakna anak lakilaki yang tampan (Dewa Indra) dan cerdas (Dewa Krisna); dan Dewi Proborini bermakna anak perempuan yang cantik seperti Dewi Suprobo. Gambaran tersebut dapat diringkas dalam bagan berikut.

\section{MAKNA "BAHASA NAMA" DALAM TRADISI JAWA}

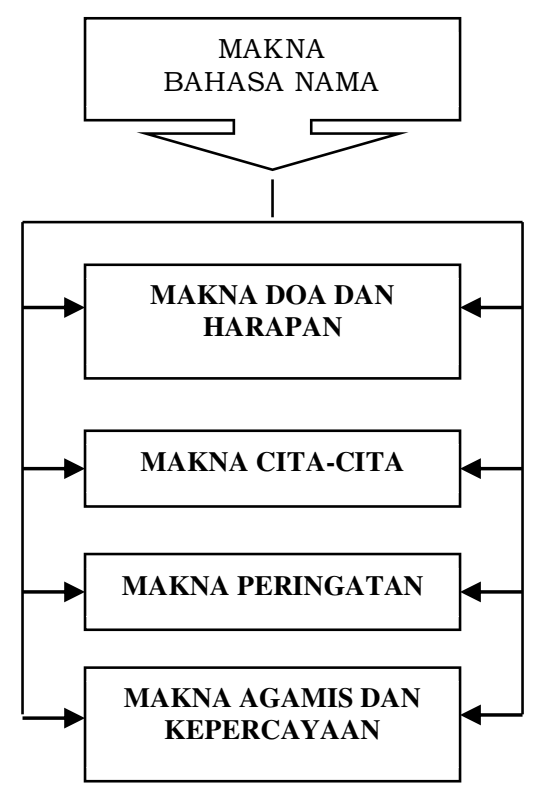

\section{SIMPULAN}

Model nama-nama yang demikian itu secara relatif masih diyakini dan dipercaya oleh sebagian kalangan masyarakat Jawa, khususnya yang memiliki akar budaya Jawa cukup baik. Namun, dengan semakin heteroginnya (beragam) agama, kepercayaan, tingkat pendidikan, dan pengaruh media massa yang demikian gencar dan mengglobal dalam dunia modern yang hampir tanpa batas ini, menjadikan budaya bahasa nama yang terikat tradisi semakin bergeser. Apalagi yang terjadi di kalangan keluarga muda di perkotaan, relatif nyaris terputus hubungannya dengan budaya leluhur karena kurangnya sambung budaya baik di tingkat keluarga, masyarakat, ataupun dunia pendidikan. Akibatnya konsistensi dan kontinyuitas pewarisan dan pengembangan nilai bahasa nama sebagai aspek tradisi adiluhung (nilai luhur) bangsa Jawa semakin menjauhi akar budayanya.

Fakta tersebut tentu merupakan kegagalan dan kemunduran budaya dalam 
tataran aplikasi. Melalui keluarga dan pendidikan pemahaman aspek nilai positif diharapkan dikembangkan di masa depan, dan tidak bersikap latah untuk mengubah dan meninggalkan tradisi tanpa menggunakan hati nurani. Sebagai orang Jawa, semestinya bersikap arif untuk: Melu Handarbeni (merasa ikut memiliki), Melu Hangrungkebi (ikut memperjuangkan), dan Mulat Sarira Hangrasa Wani (berani introspeksi diri tentang tingkat kontribusi diri) terhadap kehidupan bahasa dan budayanya sendiri. Nasib bahasa dan budaya Jawa bergantung pada tingkat kepedulian dan kemauan keras orang Jawa untuk memperjuangkannya.

\section{DAFTAR RUJUKAN}

Chaer, Abdul, Leonie Agustina. 1995. Sosiolinguistik, Perkenalan Awal. Jakarta: Penerbit Rineka Cipta. Jakarta.

Ciptoprawiro, Abdullah. 1986. Filsafat Jawa. Jakarta: Penerbit Balai Pustaka.
Haryanto, S. 1992. Bayang-Bayang Adiluhung: Filsafat, Simbolis, dan Mistik dalam Wayang. Semarang: Effhar dan Dahar Fize.

Koentjaraningrat. (1984). Kebudayaan Jawa. Jakarta: PN Balai Pustaka.

Ohoiwutun Paul. 1987. Sosiolinguistik, Memahami Bahasa dari Konteks Masyarakat dan Kebudayaan. Jakarta: Kesaint Blanc. Jakarta.

Poerwadarminta, W.J.S. 1939. Baoesastra Djawa. Batavia: J.B Wolters.

Soedarsono. RM, Gatut Murniatmo. 1986. Nilai Anak dan Wanita Dalam Masyarakat Jawa. Yogyakarta: Depertemen Pendidikan dan Kebudayaan Direktorat Jendral kebudayaan Proyek Penelitian dan Pengkajian Kebudayaan Nusantara, Bagian Jawa. Jogjakarta.

\section{UCAPAN TERIMA KASIH}

Kepada semua pihak yang telah membantu proses dimuatnya tulisan ini, penulis mengucapkan terima kasih, terutama kepada penyunting Jurnal Lokabasa. 